\title{
Erratum to: Selective laser melted titanium implants: a new technique for the reconstruction of extensive zygomatic complex defects
}

\author{
Horatiu Rotaru ${ }^{{ }^{*}}$, Ralf Schumacher ${ }^{2}$, Seong-Gon Kim ${ }^{3}$ and Cristian Dinu ${ }^{1}$
}

\section{Erratum}

After the "Competing interests" section in the original version of this article [1], an "Acknowledgements" section should be inserted and read as: "This study was partially funded by POSDRU grant no. 159/1.5/S/136893 - Parteneriat strategic pentru cresterea calitatii cercetarii stintifice din universitatile medicale prin acordarea de burse doctorale si postdoctorale - DocMed.Net_2.0".

\footnotetext{
Author details

'Department of Oral and Cranio-Maxillofacial Surgery, "Iuliu Hatieganu" University of Medicine and Pharmacy, Str. Motilor Nr. 33, Cluj-Napoca 400001, Romania. ${ }^{2}$ School of Life Sciences, Institute for Medical and Analytical Technologies, University of Applied Sciences and Arts Northwestern Switzerland, Muttenz, Switzerland. ${ }^{3}$ Department of Oral and Maxillofacial Surgery, Gangneung-Wonju National University, Gangneung, South Korea.
}

Received: 18 March 2015 Accepted: 25 March 2015

Published online: 08 April 2015

\section{Reference}

1. Rotaru H, Schumacher R, Kim SG, Dinu C (2015) Selective laser melted titanium implants: a new technique for the reconstruction of extensive zygomatic complex defects. Maxillofacial Plastic and Reconstructive Surgery $37: 1$

\footnotetext{
* Correspondence: hrotaru@yahoo.com

'Department of Oral and Cranio-Maxillofacial Surgery, "Iuliu Hatieganu" University of Medicine and Pharmacy, Str. Motilor Nr. 33, Cluj-Napoca 400001, Romania
}

Submit your manuscript to a SpringerOpen ${ }^{\odot}$ journal and benefit from:

- Convenient online submission

- Rigorous peer review

- Immediate publication on acceptance

- Open access: articles freely available online

- High visibility within the field

- Retaining the copyright to your article

Submit your next manuscript at $\boldsymbol{\wedge}$ springeropen.com 